\title{
Article \\ Metacommunity Concepts Provide New Insights in Explaining Zooplankton Spatial Patterns within Large Floodplain Systems
}

\author{
Baogui Liu ${ }^{1,2}$, Chuanqiao Zhou ${ }^{2}$, Lilin Zheng ${ }^{3}$, Haixin Duan ${ }^{2}$, Ying Chen ${ }^{2}$ and Guoxiang Wang ${ }^{2, *}$ \\ 1 School of Geography, Nanjing Normal University, Nanjing 210023, China; bgliu@njnu.edu.cn \\ 2 School of Environmental, Nanjing Normal University, Nanjing 210023, China; \\ chuanqiaozhou@163.com (C.Z.); 15895918358@163.com (H.D.); chenying7023@163.com (Y.C.) \\ 3 Key Laboratory of Geographic Information Science (Ministry of Education), School of Geographic Sciences, \\ East China Normal University, Shanghai 200241, China; zhenglilin17@mails.ucas.ac.cn \\ * Correspondence: wangguoxiang@njnu.edu.cn; Tel.: +86-139-5169-8328
}

check for updates

Citation: Liu, B.; Zhou, C.; Zheng, L.; Duan, H.; Chen, Y.; Wang, G. Metacommunity Concepts Provide New Insights in Explaining Zooplankton Spatial Patterns within Large Floodplain Systems. Water 2022, 14, 93. https://doi.org/ 10.3390/w14010093

Academic Editors: Wenqing Shi, Ming Kong and Yongqiang Zhou

Received: 13 November 2021 Accepted: 29 December 2021 Published: 4 January 2022

Publisher's Note: MDPI stays neutral with regard to jurisdictional claims in published maps and institutional affiliations.

Copyright: (c) 2022 by the authors. Licensee MDPI, Basel, Switzerland. This article is an open access article distributed under the terms and conditions of the Creative Commons Attribution (CC BY) license (https:// creativecommons.org/licenses/by/ $4.0 /)$.

\begin{abstract}
Flood pulse related physical variables (FLOOD) can affect zooplankton community structure through local factors directly and can also influence through regional dispersal factors of metacommunity concepts indirectly. Therefore, we infer that spatial patterns of zooplankton communities could be related to metacommunity concepts and their importance may depend on the size of the aquatic/terrestrial transition zone (ATTZ). Herein, we explored the relative importance of limnological (LIMNO) and FLOOD variables in zooplankton community by analyzing data from 272 sites across three floodplain lakes in the middle reaches of the Yangtze River. Our results showed that the variation in the zooplankton community can be well explained by the LIMNO and FLOOD variables in all of the lakes under the low water level season. However, during the high water level season, neither LIMNO nor FLOOD can explain the spatial variances of zooplankton. Therefore, our results indicated that testing biogeographical theories and macroecological laws using zooplankton should consider temporal aspects of flood pulse. Furthermore, we noted that the number of explained variance by local variables is negatively correlated with the size of the ATTZ. Metacommunity concepts provide complementary insights in explaining zooplankton spatial patterns within large floodplain systems, which also provide a theoretical basis for ATTZ protection in floodplain management.
\end{abstract}

Keywords: habitat heterogeneity; biotic homogenization; niche theory; neutral theory; lateral complexity

\section{Introduction}

Large floodplain lakes, which are characterized by large ranges of water level variation and large areas of aquatic/terrestrial transition zone (ATTZ), serve as important habitats for many organisms [1]. The heterogeneous habitats and the spatial pattern of aquatic communities in large floodplain lakes are mainly determined by their flood pulse. The flood pulse concept states that the pulsing of river discharge and water level variation is the major driving force responsible for the existence, productivity, and interactions of biota in river-floodplain systems [2]. Similarly, niche theory hypothesizes that heterogeneous habitats offer more niches and thus promote enhanced diversity of spatial patterns [3]. For instance, the spatial variation of the zooplankton community is frequently attributed to physical environmental features within a floodplain ecosystem [4,5]. However, the rule of flood pulse on zooplankton spatial patterns including local and regional aspects is still unclear from the perspective of the metacommunity framework.

The conceptual framework of metacommunity has been proven to be theoretically and empirically useful in understanding complex patterns of distribution, abundance, and interaction of species across multiple scales of spatiotemporal organization. In addition, it has progressed rapidly in recent years [6]. With multivariate variance partitioning for fish, chironomids, odonates, molluscs, oligochaetes, and macrophytes, Reckendorfer and Funk [7] found that environmental and spatial factors significantly affect the structure of the 
different communities. The success of metacommunity theory in interconnected ecosystems and in discrete habitat patches [8-10] suggests the possible application of metacommunity frameworks in floodplain ecosystems.

In river-floodplain lake systems, the relative importance of local and regional environmental variables for zooplankton community structure changes temporally with the dynamics of flood pulse. For instance, local factors explain a significant portion of the variation in the zooplankton community in the dry season, while spatial factors are more influential than environmental factors in the flood season [11]. Meanwhile, local environmental factors may also exert a considerably greater and continuous influence on the zooplankton community in the face of high dispersal rates [9]. Accordingly, beta diversity is predicted to be higher in floodplain lakes during periods of low than in high water level [12]. Therefore, we expect that zooplankton spatial distribution patterns can be well explained by the local process during the low water level season. In addition, the strong flood pulse may mediate local variables in structuring zooplankton community during the high water level season. Furthermore, Heino, Melo [6] stressed that future studies should explore temporal aspects of metacommunity dynamics rather than basing conclusions on a single snapshot survey in his review of metacommunity organization, spatial extent, and dispersal in aquatic systems. However, most of these studies consider only a yearly snapshot of zooplankton community structure while ignoring flood pulse dynamics.

Metacommunity and flood pulse concepts are two independent conceptual frameworks in the community ecology of aquatic organisms [2,13]. However, the metacommunity frameworks have somewhat distinct explanations on spatial patterns of aquatic organisms compared with the flood pulse concepts. From a metacommunity point of view, flood pulse dynamics, which make the water surface area expand and shrink dramatically, have made large floodplains a model environment to analyze the significance of niche assembly and dispersal assembly processes in structuring zooplankton communities [7,14]. However, the spatial heterogeneity and temporal stochasticity also present unique challenges for testing these theories. The reason may be that the idea of metacommunity is inspired by the theory of island biogeography, and the discrete habitat patches (e.g., the island-like ponds and lakes) have been intensively used [15]. However, few studies have incorporated large floodplain systems into their design, especially on zooplankton.

To explore the degree of explanation of metacommunity concepts on spatial patterns of crustacean zooplankton (hereinafter zooplankton) in lakes with flood pulse, we select three interconnected floodplain lakes located in the Yangtze River basin, at similar latitudes but with quite different areas and ratios of ATTZ. Our study aims to (1) incorporate the metacommunity framework into large floodplain lakes and (2) verify whether the zooplankton community responds differently to the local processes under different flood pulse dynamics. Herein, we infer that metacommunity concepts will explain zooplankton spatial distribution patterns well in lakes with large ATTZ. Meanwhile, the role of flood pulse concept in explaining zooplankton spatial distribution patterns may be weakened by the large ATTZ.

\section{Materials and Methods}

\subsection{Study Area}

The Yangtze River is China's longest and the world's third longest river with a length of $6300 \mathrm{~km}$, and it functions as the fourth largest source of water supply to the oceans after the Amazon, Zaire, and Orinoco Rivers. The floodplain lakes in our study are highly interconnected with this large river (Figure 1a). Lake Poyang and Dongting (PY and DT) are the largest and the second-largest floodplain lake in China with corresponding large volumes of $295 \times 10^{8} \mathrm{~m}^{3}$ and $155 \times 10^{8} \mathrm{~m}^{3}$ [16,17]. Lake DT was once the largest floodplain lake, which reached its maximum surface area of $6300 \mathrm{~km}^{2}$ in 1825 [18]. The lake surface area of DT has been reduced by approximately $40 \%$ and is now the secondlargest freshwater lake in China. Land reclamation through levee construction accounts for approximately $73 \%$ of the total lake loss since the 1930s, and the total arable land in the lake 
region increased by $1800 \mathrm{~km}^{2}$ from the early 1950s to the late 1970s [18,19]. Accordingly, the lake volume decreased and $60 \%$ of the floodplain was lost. Presently, lake PY has a drainage area of $162,000 \mathrm{~km}^{2}$, with an average yearly runoff from outlets of $1460 \times 10^{8} \mathrm{~m}^{3}$. Lake DT has a drainage area of $257,000 \mathrm{~km}^{2}$, and the average yearly runoff from outlets is $3021 \times 10^{8} \mathrm{~m}^{3}$. The large floodplain regions of lake DT and PY are included in the "Ramsar Convention on Wetlands of International Importance Especially as Waterfowl Habitat" [20]. Lake JS was once a part of lake PY but was isolated from the main channel by a dam in 1959. As a result, the lake is used for aquaculture, and the water level is controlled with a sluice.
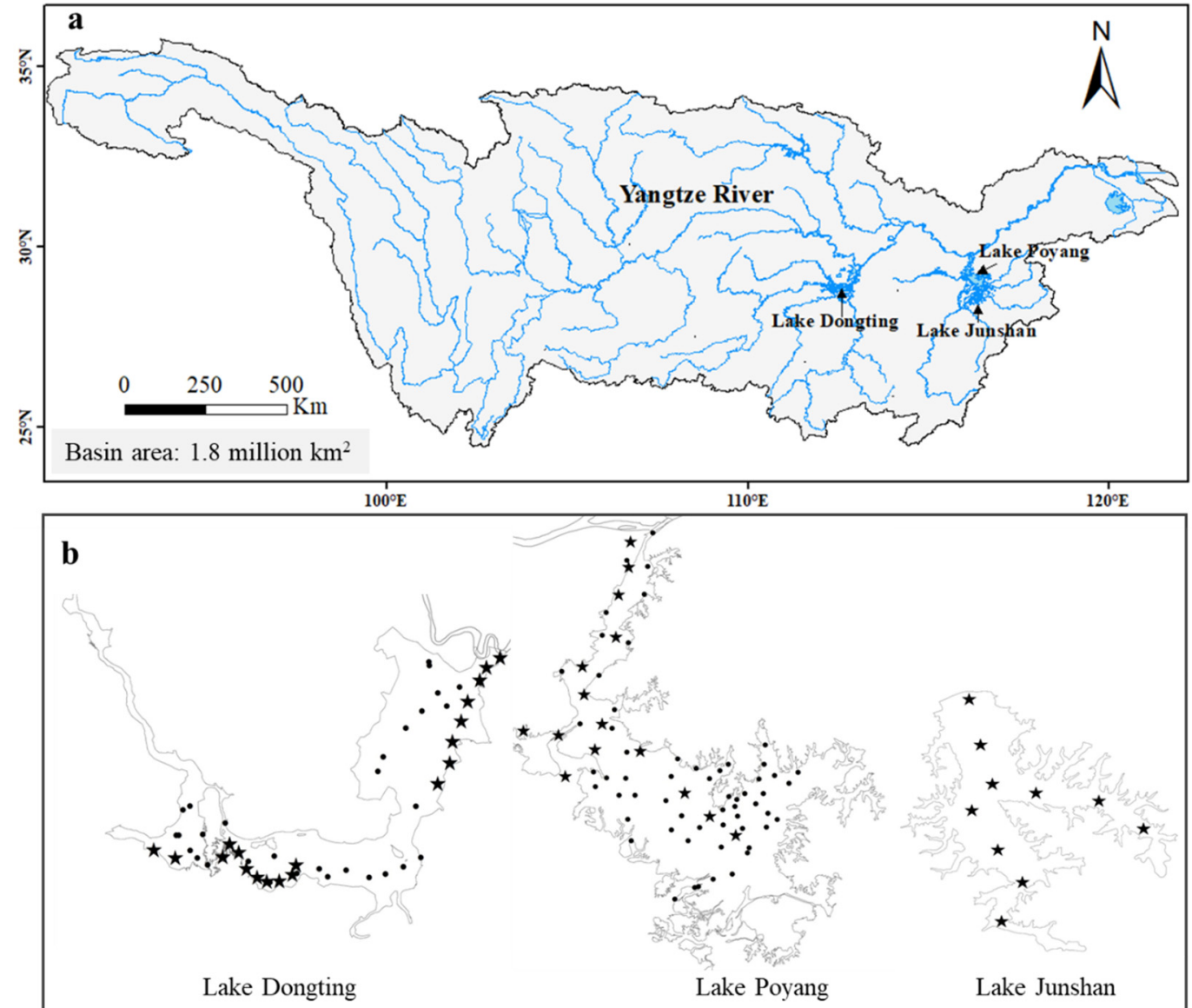

Figure 1. Location of lakes Poyang (PY), Dongting (DT), and Junshan (JS) in the Yangtze River basin (a). The enlarged drawings (b) show sampling sites only in the high water level season (solid dots) and sites in the high and low water level season (stars).

\subsection{Sampling}

Water samples were collected in July (the high water level season) of 2012 and 2013 and in January of 2013 (the low water level season). All of the riverine regions are inundated throughout the year, but most of the floodplain regions dry out in the low water level season. Therefore, only sites in riverine zones (Figure 1b) were sampled in the low water level season, the numbers are 23 and 19 for PY and DT, respectively. In the high water level season, sites in the riverine and floodplain regions were sampled (Figure 1), the numbers are 68 and 32, respectively. The water surface area of lake JS changes insignificantly between seasons. Therefore, the sampling sites were identical $(=10)$ in the high and low water level seasons. Zooplankton samples were taken twice with a $5 \mathrm{~L}$ organic glass sampler $0.5 \mathrm{~m}$ below the surface, passed through a $64 \mu \mathrm{m}$ mesh plankton net, and preserved with $4 \%$ formalin. All of the cladoceran individuals were counted and identified to the species level under a stereomicroscope (maximum magnification $\times 120$ ) where possible. Larval and 
juvenile stages were treated as taxonomic entities and included in the synchrony analyses for the copepods, given that these analyses consider only group abundance and not species richness. Crustacean biomass was estimated using the body-weight formula [21].

Water temperature, Oxido-reduction Potential, $\mathrm{pH}$, turbidity, and electrical conductivity were obtained using a Hydrolab Datasonde 5 sensor (OTT HydroMet, Loveland, CO, USA) in situ. Other local environmental variables (e.g., nutrient parameters and $\mathrm{COD}_{\mathrm{Mn}}$ ) used in this study were sampled and analyzed as described in APHA [22].

\subsection{Statistical Analysis}

All of the testing was performed with the $\mathrm{R}$ version 3.6 ( $\mathrm{R}$ Core Development Team). Only taxons present in $>25 \%$ of the samples were considered to minimize the number of zeros in the biological data [23]. The data were transformed to the natural logarithm $[\ln (1+\mathrm{x})]$ to conform to assumptions of normality, if necessary. The species dataset was Hellinger-transformed before RDA. Considering that our goal was to evaluate the actual similarities between communities rather than emphasizing the role of rare species, we used untransformed proportional species abundances to explore the similarities between the sites and test the differences between the three lakes [24]. We used the method of "analysis of similarity" (ANOSIM,) based on the Bray-Curtis dissimilarity measure with 999 permutations [25], and we also performed a non-metric multidimensional scaling analysis (NMDS) to reflect the ordination of sites and reduce the deviations of sample size on ANOSIM. NMDS was performed via the "metaMDS" function, and the data were transformed with the Hellinger standardization method via "decostand" function. To test the significant level of dissimilarity among the three lakes, we performed permutational multivariate analysis of variance (PERMANOVA), employing distance matrices via the "Adonis" function. The population and environmental synchrony were estimated via Spearman's and Pearson's mean cross-correlation, respectively. Their significance level was estimated by Monte Carlo permutations. Methods for canonical ordination and variation partitioning were offered in the Supplementary Data.

Owing to the spatial configuration of connections between lakes and rivers, using distance variables such as Euclidean distance and topology of the dispersal network, is inappropriate. Therefore, a consideration of the actual configuration of dispersal networks in these lakes is unrealistic. As a result, we split the environmental variables into two subsets, namely flood pulse related physical variables (FLOOD factors: Flow velocity, water depth, the amplitude of water level fluctuations, alimentation coefficient, floodplain area ratio, and water exchange cycle) and limnological variables (LIMNO factors: Salinity, degree of mineralization, Secchi depth, water temperature, $\mathrm{pH}$, chlorophyll a, oxidation-reduction potentiometer, total nitrogen, total phosphorous, chemical-oxygen demand, turbidity, and $\mathrm{NH}_{4}$ ). The former was normally taken as hydrological physical factors in the flood pulse concept (i.e., as local factors), but can also be partly taken as proxies for regional factors of dispersal in the metacommunity concept. The partial redundancy analysis (pRDA) determines whether LIMNO significantly explains the zooplankton species patterns when the effect of the FLOOD is held constant. The relative importance of FLOOD and LIMNO factors in affecting zooplankton community distributions was tested by variation partitioning (vPAR). During the analysis, variance inflation factors (VIF) were compared to remove significant collinear factors (e.g., salinity, degree of mineralization, and conductivity). The ANOSIM, NMDS, PERMANOVA, pRDA, and PERMIDISP function could be found in "vegan" package.

The amplitude of water level fluctuations (1), alimentation coefficient (2), floodplain area ratio (3), and water exchange cycle (4) of each lake were calculated by the following equation: 
[amplitude of water level fluctuations (m) $=$ Averaged (highest - lowest) water level

$$
\begin{gathered}
{[\text { alimentation coefficient }]=\frac{\text { drainage area }\left(\mathrm{km}^{2}\right)}{\text { Averaged highest water surface area }\left(\mathrm{km}^{2}\right)}} \\
{[\text { floodplain ratio }(\%)]=\frac{\text { Averaged }(\text { highest }- \text { lowest }) \text { water surface area }\left(\mathrm{km}^{2}\right)}{\text { multi year mean maximum surface area }\left(\mathrm{km}^{2}\right)} \times 100 \% .} \\
{[\text { water exchange cycle }(\text { days })]=\frac{\text { lake volume }\left(\mathrm{m}^{3}\right)}{\text { yearly runoff of outlets }\left(\mathrm{m}^{3}\right)} \times 365 \text { days }}
\end{gathered}
$$

\section{Results}

The water surface area (Figure 2) of the two large floodplain lakes expand and shrink relative to the seasonal changes in water level. During the flood season, the water surface areas of lake PY and DT expand to $2933 \mathrm{~km}^{2}$ and $2432.5 \mathrm{~km}^{2}$, respectively, which provides a lotic main channel and a lotic floodplain wetland and lentic backwater habitats to aquatic organisms. In contrast, their main lake areas during the dry season shrink to $146 \mathrm{~km}^{2}$ and $311 \mathrm{~km}^{2}$, respectively, which provides only riverine habitats. The water surface area of lake JS is usually $220 \mathrm{~km}^{2}$, while it has a water surface area of $180 \mathrm{~km}^{2}$ in the low water level season.

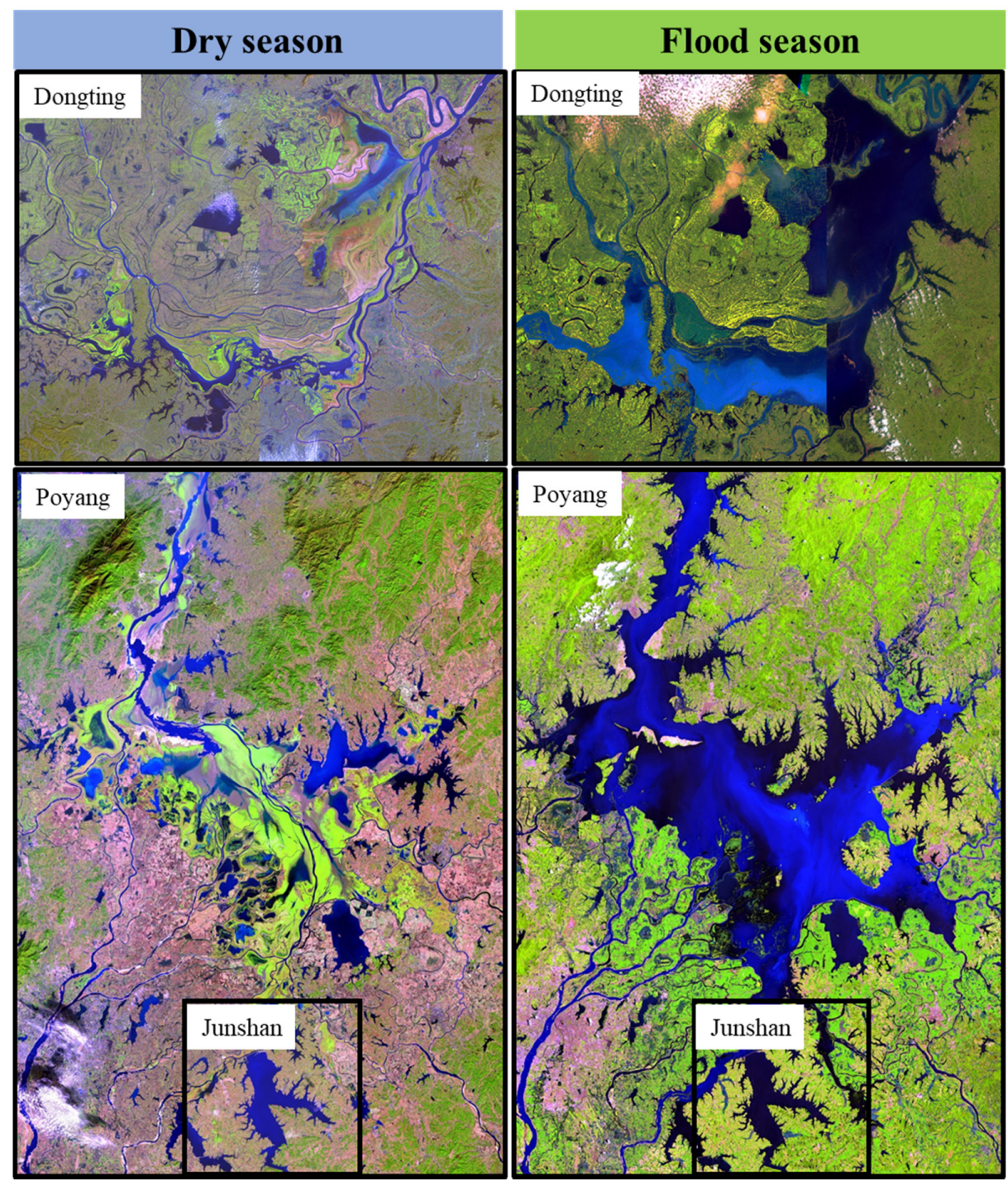

Figure 2. Spatial horizontal size of the aquatic/terrestrial transition zone of Lake Poyang, Dongting, and Junshan as reflected by comparing satellite imageries of dry (left) and flood (right) seasons. 
Four flood pulse related hydrological variables were compared between the floodplain lakes (Figure 3). The hydrological processes in DT are characterized by the largest range in water level $(13 \mathrm{~m})$, the largest alimentation coefficient (105.7), and the shortest water exchange cycle (18.8 days) of the three lakes. Comparatively, lake PY has a relatively large surface area and the largest floodplain ratio (95\%), but a relatively lower alimentation coefficient (55.0). Therefore, the hydrological processes in lake PY are less intense. For instance, the average range in water level is $7 \mathrm{~m}$ and the water exchange cycle is 74 days. The hydrological processes of lake JS are artificially controlled, with a water exchange cycle of 350 days. Although its yearly averaged range of the water level is $3 \mathrm{~m}$, the water surface area only changes insignificantly (floodplain ratio of 18\%). A comparison of physicochemical environmental variables between lake DT, PY, and JS was offered in Table S1 of the Supplementary Data.
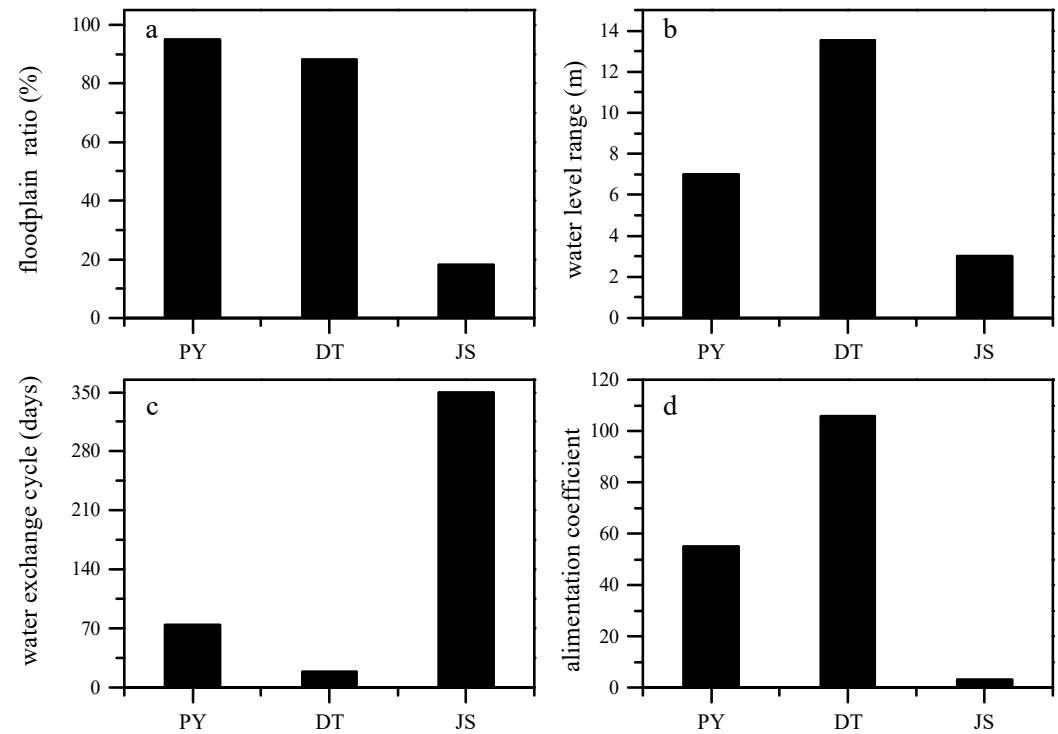

Figure 3. Floodplain ratios (a), water level ranges (b), water exchange cycles (c), and alimentation coefficients (d) of lake Poyang (PY), Dongting (DT), and Junshan (JS).

The bimultivariate redundancy statistic showed that the local process explained $26.3 \%$ (adjusted $\mathrm{R}^{2}=0.196$ ) and $49 \%$ (adjusted $\mathrm{R}^{2}=0.282$ ) of inter-lake zooplankton variances in the high and low water level seasons, respectively.

During the flood seasons, the results of pRDA showed that environmental variables could explain $85.6 \%$ of the variation in the zooplankton community in lake JS, while the figure was only $33.2 \%$ and $20.7 \%$ in lake DT and PY, respectively. Specifically, LIMNO factors explained $7.5 \%, 22.9 \%$, and $57.4 \%$, and FLOOD factors explained $13.2 \%, 10.3 \%$, and $28.2 \%$ of the variance in lake PY, DT, and JS, respectively (Figure $4 \mathrm{a}$ ). The vPAR showed similar results: $40.4 \%, 15.4 \%$, and $12.8 \%$ of zooplankton variances could be explained in lake JS, DT, and PY, respectively. Among them, LIMNO independently explained the majority of the variances in the dammed lake JS (25.6\% of $40.4 \%)$ and in the lake DT (11.4\% of $15.4 \%$ ). Neither LIMNO nor FLOOD can well explain the variances of the floodplain lake PY.

Correspondingly, the results of pRDA showed that environmental variables explained $85.5 \%, 60.4 \%$, and $56.9 \%$ of the variation in the zooplankton community in lake JS, DT, and PY during the low water level season. Among them, LIMNO factors accounted for 74.8\%, $38.2 \%$, and $29.2 \%$ (FLOOD factors for 10.7\%, 22.2\%, and 27.7\%) of the variances in lake PY, DT, and JS, respectively (Figure $4 \mathrm{~b}$ ). The vPAR showed that $56.6 \%, 20.9 \%$, and $13.7 \%$ of the variances could be explained in lake JS, DT, and PY, respectively. LIMNO independently explained the majority of the variances in the dammed lake JS (25.6\% of $40.4 \%)$ and in the leveed lake DT (14.2\% of $20.9 \%)$. 


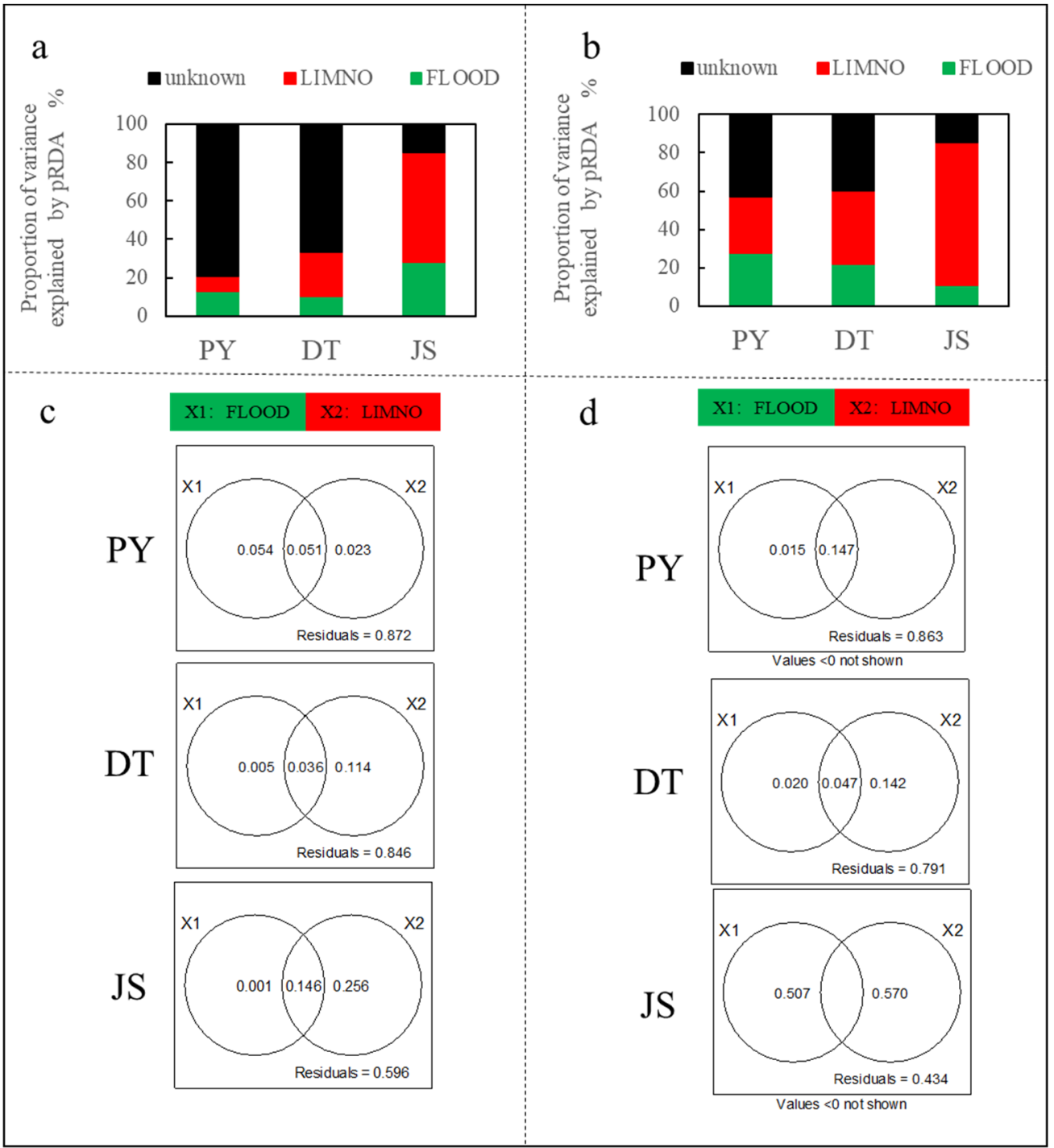

Figure 4. Partial redundancy analysis between zooplankton biomass and 16 environmental variables during the high water level (a/c) and low water level seasons (b/d) conducted for lake Poyang (PY), L. Dongting (DT), and L. Junshan (JS). The variation explained by environmental variables are displayed with the percentage stacking charts $(\mathbf{a}, \mathbf{b})$ and the Venn diagrams $(\mathbf{c}, \mathbf{d})$.

In addition, the results which are not central but important to the paper, such as zooplankton compositions (Figure S1), their ANOSIM (Figure S2), and the NMDS (Figure S3) analysis were offered in the supplementary materials.

\section{Discussion}

The "flood pulse concept" states that flood pulse may create homogeneity in tropical lowland floodplain systems, which is also known as flood homogenization [26]. Indeed, considerable literature shows that heterogeneity of plankton communities would be decreased when flood pulse occurs and floodplain regions are abundant (e.g., [12,27-30]). Various studies in the Amazonian floodplain system [31] and in the Upper Parana' River system [32] have also confirmed that floods can decrease environmental heterogeneity and zooplankton beta diversity among aquatic habitats of floodplain systems. However, our result of ANOSIM (Figure S2) implies that the within-lake dissimilarity of zooplankton communities in lake PY and DT was as high as the between-lake dissimilarity (spatial heterogenization). The result is consistent with the former study conducted in lake PY, which indicated that zooplankton biomass and body size showed a major horizontal het- 
erogenization during the flood seasons [33]. However, the spatial heterogenization, which is incompatible with the flood pulse concept, could be well explained by the metacommunity theory. According to the metacommunity concept, larger scales tend to have greater environmental heterogeneity and may reveal different patterns from those that would be observed on a smaller scale [34]. Indeed, the water surface area of lake PY and DT could reach up to $2933 \mathrm{~km}^{2}$ and $2432 \mathrm{~km}^{2}$ from $146 \mathrm{~km}^{2}$ and $311 \mathrm{~km}^{2}$, respectively. Meanwhile, the ATTZ inundated by water could reach up to $95 \%$ and $88 \%$ of the total water surface area. The ATTZ at the inside lake scale is even larger than the largest spatial scales studied in most of the former studies focusing simply on the metacommunity or flood pulse theory, such as Donau-Auen National Park in Austria [35] and in upper Parana River in Brazil [36].

The "metacommunity concept" proposes that the local process is the important driving force responsible for the existence, productivity, and interactions of zooplankton in heterogeneous habitats [6,9]. However, our quantitative results of pRDA and vPAR showed that spatial heterogeneity of zooplankton in the two floodplain lakes could not be well predicted by the local environmental stressors (residuals $>0.8$ ). Dias, Simoes [36] conducted a similar quantitative analysis and used the principal coordinates of neighbor matrix analysis derived from the geographical coordinates of the lakes and fishery data, but they similarly found an overall, very low explained variability. Therefore, the main factors responsible for the heterogeneity of zooplankton in large floodplain lakes are still unclear to date. Possible explanations could be some neglected ecological aspects including, but not limited to, the indirect biotic factors [37-39], stochastic processes [40,41], and other unmeasured environmental variables. The low explained variability, in turn, are in accordance with the flood pulse concept: High lateral complexity in large floodplain lakes is mediated through flood pulse, which therefore has a strong influence on the zooplankton community [11]. Flood pulse associated with high hydrological connectivity would highlight the importance of spatial and stochastic processes [42,43] in structuring the zooplankton community [44-48].

Our results suggest that the flood pulse concept and metacommunity theory show the complementary function in explaining the zooplankton spatial distribution in large floodplain lakes during the high water level season. The power of the local process in structuring spatial patterns of zooplankton was mediated by flood pulse, while the homogenizing force of flood pulse was buffered by the spatial scale ATTZ. Our applications of metacommunity frameworks in floodplain lakes are also important for ATTZ management [49], such as levee and dam construction. Hydrological regulations change the natural dynamics of flood pulse and can be considered a major threat to floodplain ecosystems [50-52]. Globally, habitat degradation-induced alterations of floodplain heterogeneity/homogeneity have resulted in shifts in the biodiversity of natural communities [53-56]. Therefore, assessing the effects of hydrological regulations on ecology has received increasing attention [57]. Indeed, our results imply that ATTZ degradation may alter the community of zooplankton. We noticed that the zooplankton spatial dissimilarity in lake DT is significantly lower than in lake PY during the flood seasons, which may indicate that floodplain loss $[50,58]$ has led to degradation of zooplankton spatial heterogeneity. Therefore, we propose that the size of ATTZ may be crucial for the spatial dissimilarity of zooplankton given that the floodplains may act as a buffer zone reducing flood pulse, which increases spatial variability, and as drivers for spatial heterogeneity [28,59]. Dam construction has stabilized the hydrological condition of lake JS and reduced the extent of the seasonally flooded area and the duration of floods [57,60]. Overall, our results are consistent with the few studies that analyzed metacommunities in river-floodplain systems [7], which showed that environmental factors alone explained a large amount of the higher zooplankton variation when the flood pulse is weak [11]. For example, Dias, Simoes [36] found that the importance of environmental and spatial predictors increases in explaining the distribution of microorganisms during periods of low water level and long residence time in the upper Parana River floodplains. During droughts, environmental conditions are more important for maintaining the populations in biotopes and organisms can be led to seek new delimitations of their niches [32]. Similarly, 
beta diversity is predicted to be higher in floodplain lakes during periods of low than high water levels [12,61].

Ours and many others studies clearly show that testing biogeographical theories and macroecological laws using small organisms within a one-time spatial survey may probably draw serious inconsistent conclusions (for phytoplankton see [62] and for bacteria see [63]). The "metacommunity concept" reconciles regional and local dynamics in a more inclusive theory of community assembly. Currently, the successful use of the unifying concept of the metacommunity in macroorganisms in freshwater ecosystems (e.g., fishes [8], gastropods [14], macroinvertebrates [64], etc. [7]) suggests the possible application of this model in a diverse suite of small organisms with a short life cycle $[6,62,65]$. The empirical attention on metacommunity is silently assuming that all of the study objects in correlating the microorganism's community structure to environmental variables in these multi-system observational studies show temporal coherence. However, no synchronous fluctuations in microorganisms is observed among the locations within a geographic region, especially in river systems where the environmental conditions have high temporal variations. A one-time analysis that captures major spatial biodiversity patterns of small organisms is nearly impossible. Presumably, different sizes of aquatic organisms have different abilities to handle turbulent environments induced by the flood pulse. Therefore, our empirical results support research prospects of Heino, Melo [6], which mentioned that future studies should encourage exploring temporal aspects of metacommunity organization.

\section{Conclusions}

Our study highlights the importance of large ATTZ in maintaining the stability and heterogeneity of river-floodplain ecosystems. Our results indicated that, although flood pulse can mediate local processes in structuring the zooplankton metacommunity, flood homogenization was weakened by the large ATTZ. The application of metacommunity concepts in large floodplain systems will be helpful in creating a new understanding of the importance of floodplain lake management. Future studies should also encourage exploring temporal aspects of metacommunity organization.

Supplementary Materials: The following supporting information can be downloaded at: https: / / www.mdpi.com/article/10.3390/w14010093/s1, Figure S1: Cladoceran (a,c) and copepod (b,d) biomass dynamics of Lake Poyang (PY), Dongting (DT) and Junshan (JS) during the low-water level season (-D) and the high water level season (-W); Figure S2. Analysis of cladoceran and copepod biomass similarity between Lakes Dongting (DT), Poyang (PY) and Junshan (JS) during the high water level season (-W, Left) and the low water level season (-D, Right). The Y axis represents the order of unifrac distance (improving) $(-1<\mathrm{R}<1$ : $-1<\mathrm{R}<0$, ingroup differences are larger than inter-group differences; $\mathrm{R}=0$, no differences; $0<\mathrm{R}<1$, in-ter-group differences are larger than ingroup differences); Figure S3: Biplot of the first two axes for the Non-metric Multidimensional Scaling (NMDS) analysis of crustacean zooplankton biomass in Lakes Poyang (PY), Dongting (DT) and Juanshan (JS) during the high-water level season (Left) and the low-water level season (Right); Table S1: Comparison of environmental variables between Dongting (DT), Lake Poyang (PY) and Junshan (JS) in the flood and dry seasons; TN: total nitrogen, TP: total phosphorus, COD: chemical oxygen demand.

Author Contributions: Conceptualization, B.L., C.Z. and G.W.; methodology, B.L. and L.Z.; software, C.Z. and H.D.; investigation, B.L.; writing-original draft preparation, B.L. and Y.C.; writingreview and editing, G.W. and Y.C. All authors have read and agreed to the published version of the manuscript.

Funding: This research was funded by the National Natural Science Foundation of China, grant number 41971043.

Institutional Review Board Statement: Not applicable.

Informed Consent Statement: Not applicable. 
Acknowledgments: We would like to express our deep thanks to Anne Mette Poulsen and Erik Jeppesen from Aarhus University for their editorial assistance.

Conflicts of Interest: The authors declare no conflict of interest.

\section{References}

1. Simoes, N.R.; Dias, J.D.; Leal, C.M.; Magalhaes Braghin, L.d.S.; Lansac-Toha, F.A.; Bonecker, C.C. Floods control the influence of environmental gradients on the diversity of zooplankton communities in a neotropical floodplain. Aquat. Sci. 2013, 75, 607-617. [CrossRef]

2. Junk, W.J.; Bayley, P.B.; Sparks, R.E. The flood pulse concept in river-floodplain systems. Can. Spec. Publ. Fish. Aquat. Sci. 1989, $106,110-127$.

3. Cardinale, B.J. Biodiversity improves water quality through niche partitioning. Nature 2011, 472, 86-U113. [CrossRef] [PubMed]

4. Bini, L.M.; Tundisi, J.G.; Matsumura-Tundisi, T.; Matheus, C.E. Spatial variation of zooplankton groups in a tropical reservoir (Broa Reservoir, São Paulo State-Brazil). Hydrobiologia 1997, 357, 89-98. [CrossRef]

5. Naselli-Flores, L.; Barone, R. Importance of water-level fluctuation on population dynamics of cladocerans in a hypertrophic reservoir (Lake Arancio, south-west Sicily, Italy). Hydrobiologia 1997, 360, 223-232. [CrossRef]

6. Heino, J.; Melo, A.S.; Siqueira, T.; Soininen, J.; Valanko, S.; Bini, L.M. Metacommunity organisation, spatial extent and dispersal in aquatic systems: Patterns, processes and prospects. Freshwat. Biol. 2015, 60, 845-869. [CrossRef]

7. Reckendorfer, W.; Funk, A. Metacommunity structure in a floodplain system: Implications for conservation and restoration. In Proceedings of the 5th Symposium for Research in Protected Areas, Mittersill, Austria, 10-12 June 2013.

8. Muneepeerakul, R.; Bertuzzo, E.; Lynch, H.J.; Fagan, W.F.; Rinaldo, A.; Rodriguez-Iturbe, I. Neutral metacommunity models predict fish diversity patterns in Mississippi-Missouri basin. Nature 2008, 453, 220-U229. [CrossRef]

9. Cottenie, K.; Michels, E.; Nuytten, N.; De Meester, L. Zooplankton metacommunity structure: Regional vs. local processes in highly interconnected ponds. Ecology 2003, 84, 991-1000. [CrossRef]

10. Urban, M.C. Disturbance heterogeneity determines freshwater metacommunity structure. Ecology 2004, 85, 2971-2978. [CrossRef]

11. Zhao, K.; Song, K.; Pan, Y.; Wang, L.; Da, L.; Wang, Q. Metacommunity structure of zooplankton in river networks: Roles of environmental and spatial factors. Ecol. Indic. 2017, 73, 96-104. [CrossRef]

12. Thomaz, S.M.; Bini, L.M.; Bozelli, R.L. Floods increase similarity among aquatic habitats in river-floodplain systems. Hydrobiologia 2007, 579, 1-13. [CrossRef]

13. Leibold, M.A.; Holyoak, M.; Mouquet, N.; Amarasekare, P.; Chase, J.M.; Hoopes, M.F.; Holt, R.D.; Shurin, J.B.; Law, R.; Tilman, D.; et al. The metacommunity concept: A framework for multi-scale community ecology. Ecol. Lett. 2004, 7, 601-613. [CrossRef]

14. Funk, A.; Schiemer, F.; Reckendorfer, W. Metacommunity structure of aquatic gastropods in a river floodplain: The role of niche breadth and drift propensity. Freshwat. Biol. 2013, 58, 2505-2516. [CrossRef]

15. Vanormelingen, P.; Cottenie, K.; Michels, E.; Muylaert, K.; Vyverman, W.; De Meester, L. The relative importance of dispersal and local processes in structuring phytoplankton communities in a set of highly interconnected ponds. Freshwat. Biol. 2008, 53, 2170-2183. [CrossRef]

16. Dou, H.; Jiang, J. Dongting Lake; Press of University of Science and Technology of China: Hefei, China, 2000.

17. Zhu, H.; Zhang, B. Poyang Lake; Press of University of Science and Technology of China: Hefei, China, 1997.

18. Zhao, S.Q.; Fang, J.Y.; Miao, S.L.; Gu, B.; Tao, S.; Peng, C.H.; Tang, Z.Y. The 7-decade degradation of a large freshwater lake in central Yangtze river, China. Environ. Sci. Technol. 2005, 39, 431-436. [CrossRef]

19. Zhou, Y.; Li, J.; Zhang, Y.; Zhang, X.; Li, X. Enhanced lakebed sediment erosion in Dongting Lake induced by the operation of the Three Gorges Reservoir. J. Geogr. Sci. 2015, 25, 917-929. [CrossRef]

20. Li, Y.L.; Zhang, Q.; Yao, J.; Werner, A.D.; Li, X.H. Hydrodynamic and Hydrological Modeling of the Poyang Lake Catchment System in China. J. Hydrol. Eng. 2014, 19, 607-616. [CrossRef]

21. Błędzki, L.A.; Rybak, J.I. Freshwater Crustacean Zooplankton of Europe; Springer: Berlin/Heidelberg, Germany, 2016.

22. APHA. Standard Methods for the Examination of Water and Wastewater; American Public Health Association (APHA): Washington, DC, USA, 2005.

23. Vieira, M.C.; Roitman, I.; Barbosa, H.d.O.; Machado Velho, L.F.; Galli Vieira, L.C. Spatial synchrony of zooplankton during the impoundment of amazonic reservoir. Ecol. Indic. 2019, 98, 649-656. [CrossRef]

24. Brown, B.L.; Swan, C.M. Dendritic network structure constrains metacommunity properties in riverine ecosystems. J. Anim. Ecol. 2010, 79, 571-580. [CrossRef]

25. Tavşanoğlu, Ü.N.; Šorf, M.; Stefanidis, K.; Brucet, S.; Türkan, S.; Agasild, H.; Baho, D.L.; Scharfenberger, U.; Hejzlar, J.; Papastergiadou, E. Effects of nutrient and water level changes on the composition and size structure of zooplankton communities in shallow lakes under different climatic conditions: A pan-European mesocosm experiment. Aquat. Ecol. 2017, 51, 257-273. [CrossRef]

26. Tockner, K.; Malard, F.; Ward, J.V. An extension of the flood pulse concept. Hydrol. Processes 2000, 14, 2861-2883. [CrossRef]

27. Mihaljevic, M.; Stevic, F.; Horvatic, J.; Kutuzovic, B.H. Dual impact of the flood pulses on the phytoplankton assemblages in a Danubian floodplain lake (Kopacki Rit Nature Park, Croatia). Hydrobiologia 2009, 618, 77-88. [CrossRef] 
28. Higuti, J.; Velho, L.F.M.; Lansac-Toha, F.A.; Martens, K. Pleuston communities are buffered from regional flood pulses: The example of ostracods in the Parana River floodplain, Brazil. Freshwat. Biol. 2007, 52, 1930-1943. [CrossRef]

29. da Conceição, E.d.O.; Higuti, J.; de Campos, R.; Martens, K. Effects of flood pulses on persistence and variability of pleuston communities in a tropical floodplain lake. Hydrobiologia 2018, 807, 175-188. [CrossRef]

30. Kobayashi, T.; Ralph, T.J.; Ryder, D.S.; Hunter, S.J.; Shiel, R.J.; Segers, H. Spatial dissimilarities in plankton structure and function during flood pulses in a semi-arid floodplain wetland system. Hydrobiologia 2015, 747, 19-31. [CrossRef]

31. Bozelli, R.L.; Thomaz, S.M.; Padial, A.A.; Lopes, P.M.; Bini, L.M. Floods decrease zooplankton beta diversity and environmental heterogeneity in an Amazonian floodplain system. Hydrobiologia 2015, 753, 233-241. [CrossRef]

32. Braghin, L.S.M.; Figueiredo, B.R.S.; Meurer, T.; Michelan, T.S.; Simoes, N.R.; Bonecker, C.C. Zooplankton diversity in a dammed river basin is maintained by preserved tributaries in a tropical floodplain. Aquat. Ecol. 2015, 49, 175-187. [CrossRef]

33. Liu, B.; Liu, J.; Jeppesen, E.; Chen, Y.; Liu, X.; Zhang, W. Horizontal distribution of pelagic crustacean zooplankton biomass and body size in contrasting habitat types in Lake Poyang, China. Environ. Sci. Pollut. Res. 2019, 26, 2270-2280. [CrossRef]

34. Kraus, C.N.; Bonnet, M.-P.; Miranda, C.A.; Nogueira, I.d.S.; Garnier, J.; Galli Vieira, L.C. Interannual hydrological variations and ecological phytoplankton patterns in Amazonian floodplain lakes. Hydrobiologia 2019, 830, 135-149. [CrossRef]

35. Chaparro, G.; Horvath, Z.; O'Farrell, I.; Ptacnik, R.; Hein, T. Plankton metacommunities in floodplain wetlands under contrasting hydrological conditions. Freshwat. Biol. 2018, 63, 380-391. [CrossRef]

36. Dias, J.D.; Simoes, N.R.; Meerhoff, M.; Lansac-Toha, F.A.; Machado Velho, L.F.; Bonecker, C.C. Hydrological dynamics drives zooplankton metacommunity structure in a Neotropical floodplain. Hydrobiologia 2016, 781, 109-125. [CrossRef]

37. Strecker, A.L.; Cobb, T.P.; Vinebrooke, R.D. Effects of experimental greenhouse warming on phytoplankton and zooplankton communities in fishless alpine ponds. Limnol. Oceanogr. 2004, 49, 1182-1190. [CrossRef]

38. Havens, K.E.; Beaver, J.R. Zooplankton to phytoplankton biomass ratios in shallow Florida lakes: An evaluation of seasonality and hypotheses about factors controlling variability. Hydrobiologia 2013, 703, 177-187. [CrossRef]

39. Havens, K.E.; Beaver, J.R.; Manis, E.E.; East, T.L. Inter-lake comparisons indicate that fish predation, rather than high temperature, is the major driver of summer decline in Daphnia and other changes among cladoceran zooplankton in subtropical Florida lakes. Hydrobiologia 2015, 750, 57-67. [CrossRef]

40. Wang, J.; Shen, J.; Wu, Y.; Tu, C.; Soininen, J.; Stegen, J.C.; He, J.; Liu, X.; Zhang, L.; Zhang, E. Phylogenetic beta diversity in bacterial assemblages across ecosystems: Deterministic versus stochastic processes. ISME J. 2013, 7, 1310-1321. [CrossRef]

41. Chase, J.M.; Myers, J.A. Disentangling the importance of ecological niches from stochastic processes across scales. Philos. Trans. R. Soc. B-Biol. Sci. 2011, 366, 2351-2363. [CrossRef] [PubMed]

42. Liu, X.; Li, Y.-1.; Liu, B.-G.; Qian, K.-M.; Chen, Y.-W.; Gao, J.-F. Cyanobacteria in the complex river-connected Poyang Lake: Horizontal distribution and transport. Hydrobiologia 2016, 768, 95-110. [CrossRef]

43. Humphries, S. Filter feeders and plankton increase particle encounter rates through flow regime control. Proc. Natl. Acad. Sci. USA 2009, 106, 7882-7887. [CrossRef]

44. Pinel-Alloul, B.; Andre, A.; Legendre, P.; Cardille, J.A.; Patalas, K.; Salki, A. Large-scale geographic patterns of diversity and community structure of pelagic crustacean zooplankton in Canadian lakes. Glob. Ecol. Biogeogr. 2013, 22, 784-795. [CrossRef]

45. Otto, S.A.; Diekmann, R.; Flinkman, J.; Kornilovs, G.; Mollmann, C. Habitat Heterogeneity Determines Climate Impact on Zooplankton Community Structure and Dynamics. PLoS ONE 2014, 9, e90875. [CrossRef]

46. Vijverberg, J.; Boersma, M. Long-term dynamics of small-bodied and large-bodied cladocerans during the eutrophication of a shallow reservoir, with special attention for Chydorus sphaericus. Hydrobiologia 1997, 360, 233-242. [CrossRef]

47. Thorp, J.H.; Mantovani, S. Zooplankton of turbid and hydrologically dynamic prairie rivers. Freshwat. Biol. 2005, 50, 1474-1491. [CrossRef]

48. Wahl, D.H.; Goodrich, J.; Nannini, M.A.; Dettmers, J.M.; Soluk, D.A. Exploring riverine zooplankton in three habitats of the Illinois River ecosystem: Where do they come from? Limnol. Oceanogr. 2008, 53, 2583-2593. [CrossRef]

49. Kong, X.; He, Q.; Yang, B.; He, W.; Xu, F.; Janssen, A.B.G.; Kuiper, J.J.; van Gerven, L.P.A.; Qin, N.; Jiang, Y.; et al. Hydrological regulation drives regime shifts: Evidence from paleolimnology and ecosystem modeling of a large shallow Chinese lake. Glob. Chang. Biol. 2017, 23, 737-754. [CrossRef]

50. Yin, H.F.; Li, C.G. Human impact on floods and flood disasters on the Yangtze River. Geomorphology 2001, 41, 105-109. [CrossRef]

51. Lougheed, V.L.; McIntosh, M.D.; Parker, C.A.; Stevenson, R.J. Wetland degradation leads to homogenization of the biota at local and landscape scales. Freshwat. Biol. 2008, 53, 2402-2413. [CrossRef]

52. Obolewski, K.; Glińska-Lewczuk, K.; Ożgo, M.; Astel, A. Connectivity restoration of floodplain lakes: An assessment based on macroinvertebrate communities. Hydrobiologia 2016, 774, 23-37. [CrossRef]

53. Vellend, M.; Verheyen, K.; Flinn, K.M.; Jacquemyn, H.; Kolb, A.; Van Calster, H.; Peterken, G.; Graae, B.J.; Bellemare, J.; Honnay, O.; et al. Homogenization of forest plant communities and weakening of species-environment relationships via agricultural land use. J. Ecol. 2007, 95, 565-573. [CrossRef]

54. Monchamp, M.-E.; Spaak, P.; Domaizon, I.; Dubois, N.; Bouffard, D.; Pomati, F. Homogenization of lake cyanobacterial communities over a century of climate change and eutrophication. Nat. Ecol. Evol. 2018, 2, 317-327. [CrossRef]

55. Smart, S.M.; Thompson, K.; Marrs, R.H.; Le Duc, M.G.; Maskell, L.C.; Firbank, L.G. Biotic homogenization and changes in species diversity across human-modified ecosystems. Proc. R. Soc. B-Biol. Sci. 2006, 273, 2659-2665. [CrossRef] 
56. Olden, J.D.; Comte, L.; Giam, X. The Homogocene: A research prospectus for the study of biotic homogenisation. Neobiota 2018, 37, 23-36. [CrossRef]

57. Zeng, L.; McGowan, S.; Cao, Y.; Chen, X. Effects of dam construction and increasing pollutants on the ecohydrological evolution of a shallow freshwater lake in the Yangtze floodplain. Sci. Total Environ. 2018, 621, 219-227. [CrossRef] [PubMed]

58. Shankman, D.; Keim, B.D.; Song, J. Flood frequency in China's Poyang Lake region: Trends and teleconnections. Int. J. Climatol. 2006, 26, 1255-1266. [CrossRef]

59. Nielsen, D.L.; Gigney, H.; Watson, G. Riverine habitat heterogeneity: The role of slackwaters in providing hydrologic buffers for benthic microfauna. Hydrobiologia 2010, 638, 181-191. [CrossRef]

60. Liu, B.; Tan, G.; Xing, J.; Li, M.; Chen, Y. Effect of Pen Culture on Community Structure of Planktonic Crustaceans in Lake Junshan. J. Ecol. Rural Environ. 2015, 31, 82-87.

61. Zhou, S.C.; Tang, T.; Wu, N.C.; Fu, X.C.; Cai, Q.H. Impacts of a small dam on riverine zooplankton. Int. Rev. Hydrobiol. 2008, 93, 297-311. [CrossRef]

62. Bortolini, J.C.; Pineda, A.; Rodrigues, L.C.; Jati, S.; Velho, L.F.M. Environmental and spatial processes influencing phytoplankton biomass along a reservoirs-river-floodplain lakes gradient: A metacommunity approach. Freshwat. Biol. 2017, 62, 1756-1767. [CrossRef]

63. Langenheder, S.; Berga, M.; Östman, Ö.; Székely, A.J. Temporal variation of $\beta$-diversity and assembly mechanisms in a bacterial metacommunity. ISME J. 2012, 6, 1107-1114. [CrossRef] [PubMed]

64. Cai, Y.; Xu, H.; Vilmi, A.; Tolonen, K.T.; Tang, X.; Qin, B.; Gong, Z.; Heino, J. Relative roles of spatial processes, natural factors and anthropogenic stressors in structuring a lake macroinvertebrate metacommunity. Sci. Total Environ. 2017, 601, 1702-1711. [CrossRef]

65. de Melo, M.L.; Bertilsson, S.; Amaral, J.H.F.; Barbosa, P.M.; Forsberg, B.R.; Sarmento, H. Flood pulse regulation of bacterioplankton community composition in an Amazonian floodplain lake. Freshwat. Biol. 2019, 64, 108-120. [CrossRef] 